\title{
Cholesterol implications in plasmid DNA electrotransfer: Evidence for the involvement of endocytotic pathways
}

\author{
Christelle Rosazza a,b,c, Emilie Phez ${ }^{\mathrm{a}, \mathrm{b}}$, Jean-Michel Escoffre ${ }^{\mathrm{a}, \mathrm{b}, 1}$, Laurence Cézanne ${ }^{\mathrm{a}, \mathrm{b}, 2}$, \\ Andreas Zumbusch ${ }^{c, *}$, Marie-Pierre Rols ${ }^{\mathrm{a}, \mathrm{b}, * *}$ \\ a Department of Structural Biology and Biophysics, CNRS, Institut de Pharmacologie et de Biologie Structurale, 205 Route de Narbonne, F-31077 Toulouse, France \\ ${ }^{\mathrm{b}}$ University of Toulouse, UPS, Institut de Pharmacologie et de Biologie Structurale, F-31077 Toulouse, France \\ ${ }^{\mathrm{c}}$ Department of Chemistry, University of Konstanz, Universitätsstraße 10, D-78457 Konstanz, Germany
}

Keywords:

Gene delivery

Electroporation

Cholesterol

Endocytosis

Colocalization analysis

\begin{abstract}
A B S T R A C T
The delivery of therapeutic molecules such as plasmid DNA in cells and tissues by means of electric fields holds great promise for anticancer treatment. To allow for their therapeutic action, the molecules have first to traverse the cell membrane. The mechanisms by which the electrotransferred pDNA interacts with and crosses the plasma membrane are not yet fully explained. The aim of this study is to unravel the role of cholesterol during gene electrotransfer in cells. We performed cholesterol depletion experiments and measured its effects on various steps of the electroporation process. The first two steps consisting of electropermeabilization of the plasma membrane and of pDNA interaction with it were not affected by cholesterol depletion. In contrast, gene expression decreased. Colocalization studies with endocytotic markers showed that pDNA is endocytosed with concomitant clathrin- and caveolin/raft-mediated endocytosis. Cholesterol might be involved in the pDNA translocation through the plasma membrane. This is the first direct experimental evidence of the occurrence of endocytosis in gene electrotransfer.
\end{abstract}

\section{Introduction}

The cell plasma membrane acts as a selective barrier controlling molecule exchange between the cell and its external environment. As many therapeutic molecules are non permeant, their targeted delivery into living cells and tissues is an important goal of modern pharmacology and therapy (Escoffre et al., 2010b). Indeed, the aim of molecule delivery methods is to efficiently overcome the cell barriers to allow for their therapeutic action. A strict localization of the pharmacological activity of therapeutic molecules to a cellular target site would result in a significant reduction of its toxicity, a reduction of its dose, and would increase treatment effectiveness.

\footnotetext{
* Corresponding author at: Fachbereich Chemie, Universität Konstanz, Universitätsstraße 10, Fach 722, D-78457 Konstanz, Germany. Tel.: +49 7531882357; fax: +497531883870

** Corresponding author at: Institut de Pharmacologie et de Biologie Structurale, CNRS UMR 5089, 205 Route de Narbonne, F-31077 Toulouse, France. Tel.: +33 561175811; fax: +33 561175900.

E-mail addresses: andreas.zumbusch@uni-konstanz.de (A. Zumbusch), mariepierre.rols@ipbs.fr (M.-P. Rols).

1 Present address: UMRS Inserm U930 “Imagerie et Cerveau”, CNRS ERL3106, Université François Rabelais de Tours, CHU Le Bretonneau, 10 Ter bd Tonnellé, 37044 Tours Cedex 9, France.

2 In memory of Laurence Dupou-Cezanne, a colleague and a friend.
}

In recent years, promising new possibilities for targeted delivery of therapeutic molecules have been developed. Some of these rely on the electropermeabilization of the plasma membrane (an approach also termed electroporation). Electropermeabilization, a physical method that consists of the application of electric pulses on cells and tissues, was introduced in the 1970s and subsequently developed in the 1980s for gene delivery (Neumann et al., 1982). It has the advantage of being very versatile, highly efficient, simple, and low in cost (Golzio et al., 2004). These attractive features have been pointed out in several reviews (Cemazar and Sersa, 2007; Gehl, 2008; Heller and Heller, 2010; Mir et al., 2003). Applications have been successfully developed for antitumor drugs (Campana et al., 2009; Landstrom et al., 2010; Mir et al., 1998; Rols et al., 2002) and gene delivery (Aihara and Miyazaki, 1998; Heller et al., 1996; Mir et al., 1999; Rols et al., 1998; Titomirov et al., 1991). Meanwhile, electrochemotherapy has been accepted in a number of countries as a palliative care treatment (Giardino et al., 2006; Sersa et al., 2008; Spugnini et al., 2008) and clinical trials of electrogenetherapy are under investigation (Daud et al., 2008; Low et al., 2009). In the latter case, plasmid DNA (pDNA) is the therapeutic agent used to transfer genetic information. Wider spread use of this approach is hampered by the fact that very little is known about the molecular and cellular mechanisms supporting the reorganization of the cell membrane which accompanies the pDNA uptake (Teissie et al., 2005). It is evident that gaining a better 
understanding of the internalization and intracellular trafficking of pDNA is a prerequisite for safe use of gene electrotransfer in clinical applications. Several theoretical models postulate that pDNA crosses the plasma membrane through "electropores" and directly accesses the cytosol during electropulsation (Escoffre et al., 2009a). However, to date such models have not been supported by experimental data performed on cells. Experiments performed on giant unilamellar vesicles (GUVs) show that electropores may be created (Portet et al., 2009) and that these electropores may allow the direct entrance of plasmid DNA into the vesicles (Portet et al., 2011). Experiments performed at the single cell level on mammalian cells show that the mechanisms of molecule delivery are much more complex. They reported phenomenological descriptions of small molecules and gene electrotransfer processes. Small molecules (below $4 \mathrm{kDa}$ ) and macromolecules (above $4 \mathrm{kDa}$ ) enter the cell through well defined cellular regions facing the electrodes. Small molecules (e.g. propidium iodide, cytotoxic drugs such as bleomycin and cisplatin) enter the cell in membrane regions facing both the cathode and anode. This diffusive flux is driven by the concentration gradient difference between the external medium and the cytosol and/or by electrophoresis (Escoffre et al., 2010a; Gabriel and Teissie, 1997; Pucihar et al., 2008). In contrast, pDNA uptake only occurs in the membrane region facing the cathode. The current understanding is that pDNA uptake requires a number of consecutive steps (Golzio et al., 2002): during the electropulsation, the plasma membrane is permeabilized, pDNA migrates electrophoretically towards the permeabilized cells, and is inserted into the permeabilized membrane. After electropulsation, pDNA translocation across the membrane occurs, and the pDNA migrates towards the nucleus and crosses the nuclear envelope (Escoffre et al., 2009a). Thus, pDNA does not enter the cell during electropulsation, but is transiently trapped in the permeabilized membrane. Its distribution in the permeabilized membrane is not homogeneous. Instead, it appears in "competent sites" whose size ranges from 0.1 to $0.5 \mu \mathrm{m}$ (Faurie et al., 2004, 2010; Golzio et al., 2002). The pDNA interacts in a yet unknown way with some microdomains of the plasma membrane, the nature of which is also not known. These "competent microdomains" have not been detected during the electrotransfer of pDNA in pure lipid membranes (Portet et al., 2011). A second important obstacle in gene electrotransfer comes from pDNA translocation across the membrane and its intracellular trafficking into the cytosol. In previous investigations, fluorescently labeled pDNA could only be detected inside the cytosol several minutes after electropulsation (Golzio et al., 2002; Jerome et al., 2009). Then it was seen as free pDNA and in aggregates. These results suggested that the pDNA could cross the membrane through pores or/and via endocytosis. The model of electroendocytosis has been suggested by several groups (Antov et al., 2004; Chernomordik et al., 1990; Glogauer et al., 1993; Klenchin et al., 1991; Mahrour et al., 2005; Rols et al., 1995; Rosazza et al., 2011; Rosemberg and Korenstein, 1997). The stimulation of fluid phase endocytosis has been reported by most of them. An increase of fluid phase markers uptake such as Lucifer Yellow or dextran has been shown to occur after electropulsation. Moreover, the internalization of membrane phospholipids was increased and the fluid phase markers uptake showed temperature dependence (Antov et al., 2004). In addition, the cytoskeleton seems to have an active involvement in the macromolecules uptake. A recent study on the actin cytoskeleton implications in the DNA electrotransfer showed the formation of actin patches colocalizing with the DNA aggregates at the membrane (Rosazza et al., 2011). Moreover, an alteration of the actin network induced a decrease in both the amount of pDNA interacting with the cell membrane and the gene expression level. Up to date, the pDNA translocation mechanism is not yet fully characterized, it is possible that both suggested models, electropores and electroendocytosis, occur at the same time as pDNA as been detected in both aggregated and free forms in the cytoplasm (Golzio et al., 2002). However, rather little data concerning the intracellular trafficking of electrotransferred pDNA which could shed light on the translocation mode have been published to date.

From what has been detailed above, we can suggest that the membrane composition is likely to affect its interaction with pDNA molecules. This in turn could influence the pathway of pDNA entry into the cell (Rejman et al., 2004). In order to verify this assumption, we investigated the role of cholesterol in the gene electrotransfer process. Cholesterol represents 30\% of membrane lipids of mammalian cells and has a major influence on the biophysical properties of the plasma membrane, such as e.g. membrane fluidity and thickness (Maxfield and Tabas, 2005). It is mainly found in the inner leaflet of the plasma membrane of cells and is also enriched in membrane domains involved in a large variety of processes such as protein transport (Yoshimori et al., 1996), signal transduction (Simons and Toomre, 2000), and pathogen entry (Fivaz et al., 1999; Lafont et al., 2004; Manes et al., 2003). Moreover, cholesterol is involved in clathrin- and caveolin/raft-mediated endocytosis (Doherty and McMahon, 2009). It plays a key role in molecule entry into cells and can therefore have a major role in the interaction of pDNA with the plasma membrane, the translocation of pDNA through the membrane, and its intracellular trafficking. The questions we address here are: Is cholesterol involved in the electropermeabilization process of the membrane? Does it participate in the formation of the pDNA interaction with the membrane? What is its effect on electroporation mediated gene delivery? How does the pDNA cross the plasma membrane? In order to answer these questions, we have performed cholesterol depletion experiments, which allow us to measure its effect on the different steps of the electroporation process. In addition, we performed colocalization studies with several endocytotic markers which give insight into the internalization pathways of pDNA.

\section{Materials and methods}

\subsection{Cell culture}

The wild-type (Toronto strain) Chinese Hamster Ovary (CHO) cell line was selected for its ability to grow in suspension in a spinner or plated on Petri dishes or on $22 \mathrm{~mm} \times 22 \mathrm{~mm}$ microscope glass coverslips (Lab-Tek ${ }^{\circledR}$ II, Nunc ${ }^{\mathrm{TM}}$, Roskilde, Denmark). $\mathrm{CHO}$ cells were grown in Eagle's minimum essential medium (MEM 1011, Eurobio, Les Ulis, France) supplemented with $8 \%$ heat inactivated fetal bovine serum (Gibco ${ }^{\circledR}$, InvitroGen ${ }^{\mathrm{TM}}$, Carlsbad, CA), $0.584 \mathrm{~g} / \mathrm{L}$ L-glutamine $\left(\right.$ Gibco $^{\circledR}$, InvitroGen ${ }^{\mathrm{TM}}$, Carlsbad, CA), $3.5 \mathrm{~g} / \mathrm{L}$ D-glucose (Sigma-Aldrich, St. Louis, MO), $2.95 \mathrm{~g} / \mathrm{L}$ tryptosephosphate (Sigma-Aldrich, St. Louis, MO), $100 \mathrm{U} / \mathrm{mL}$ penicillin $\left(\right.$ Gibco $^{\circledR}$, InvitroGen ${ }^{\mathrm{TM}}$, Carlsbad, CA), $1 \mathrm{mg} /$ L streptomycin $\left(G i b c 0^{\circledR}\right.$, InvitroGen ${ }^{\mathrm{TM}}$, Carlsbad, CA) and BME vitamins (Sigma-Aldrich, St. Louis, MO). The cells were routinely sub-cultured every 2 days and incubated at $37^{\circ} \mathrm{C}$ in a humidified atmosphere with a $5 \% \mathrm{CO}_{2}$ incubator (Golzio et al., 2002).

\subsection{Electropulsation procedure}

Electropulsation was performed using a CNRS cell electropulsator (Jouan, St. Herblain, France), which delivers square-wave electric pulses. The amplitude $(U)$, the duration $(T)$, the number $(N)$, and the frequency $(f)$ of the electric pulse train were controlled independently. An oscilloscope (Enertec, St. Etienne, France) monitored the pulse shape. For the CHO cells, the optimum electropermeabilization parameters are 10 pulses of $5 \mathrm{~ms}$ at $1 \mathrm{~Hz}$ frequency with an electric field strength between 0.4 and $0.8 \mathrm{kV} / \mathrm{cm}$ (Golzio et al., 2002). Stainless-steel electrodes were used in order 
to avoid electrochemical reactions of the metal. Several types of electrodes were used depending on the procedure to be applied: (i) parallel plate electrodes $(10 \mathrm{~mm}$ length, $5 \mathrm{~mm}$ inter-electrode distance) were used to pulse cell suspensions and (ii) parallel rod electrodes ( $10 \mathrm{~mm}$ length, $0.5 \mathrm{~mm}$ diameter, $7 \mathrm{~mm}$ gap) were used to pulse cells under fluorescence microscope (Mazeres et al., 2009). The electropulsations were performed in a low conductivity buffer (10 mM K $\mathrm{HPO}_{4} / \mathrm{KH}_{2} \mathrm{PO}_{4}$, pH 7.4, $1 \mathrm{mM} \mathrm{MgCl} 2,250 \mathrm{mM}$ sucrose), which minimized the temperature increase due to the application of the electric field. Cells were maintained in the pulsation buffer for $5 \mathrm{~min}$ after the application of the electric pulses to allow for membrane resealing.

\subsection{Cholesterol depletion}

The cholesterol depletion was performed using $5 \mathrm{mM}$ methyl$\beta$-cyclodextrin (M $\beta C D$ ) (Sigma-Aldrich, St. Louis, MO) in the culture medium without serum. Cell suspensions were washed with PBS and suspended in the depletion medium at a density of $10^{6} \mathrm{cells} / \mathrm{mL}$. They were incubated in the spinner for $15 \mathrm{~min}$ at $37^{\circ} \mathrm{C}$ with low agitation (70-100 rpm). Control cells were handled and incubated under the same conditions using the culture medium without serum. Standard techniques were used for quantitative analysis: the percentage of cholesterol depletion was evaluated according to Cezanne et al. (1992); after cell lysis and several centrifugations, the membrane proteins were quantified using the Lowry method (Lowry et al., 1951); lipids were extracted and measured as has first been described by Bligh and Dyer (1959); phosphate measurements were done according to Rouser et al. (1970), cholesterol measurements according to Zlatkis et al. (1953).

\subsection{Electropermeabilization}

A cell suspension $\left(10^{6}\right.$ cells $\left./ \mathrm{mL}\right)$ was incubated in a spinner either in the depletion medium for the $\mathrm{M} \beta C D$ treated cells or in the culture medium without serum for the control cells. After the $15 \mathrm{~min}$ incubation time, the cells were centrifuged $(5 \mathrm{~min}$, $120 \mathrm{~g}$ ). For each electropermeabilization condition $5 \times 10^{5}$ cells were suspended in $100 \mu \mathrm{L}$ pulsation buffer containing $100 \mu \mathrm{mol} / \mathrm{L}$ propidium iodide (PI). The pulse series were applied at field strengths between 0.1 and $1 \mathrm{kV} / \mathrm{cm}$, the others parameters were chosen as has been described above. After $5 \mathrm{~min}$, the cells were transferred to PBS buffer and analyzed using flow cytometry (FACScan, BD Biosciences, Le Pont de Claix, France) via the FL2 channel $\left(560 \mathrm{~nm} \leq \lambda_{\mathrm{em}} \leq 600 \mathrm{~nm}\right)$. The percentage of fluorescent cells therefore corresponds to the percentage of electropermeabilized cells (i.e. the efficiency of electropermeabilization) and the mean fluorescence intensity reflects the mean quantity of PI incorporated into the cells (i.e. the level of electropermeabilization) (Rols and Teissie, 1998).

\subsection{Interaction $\mathrm{pDNA} /$ membrane}

pEGFP-C1 plasmid (Clonetech, Palo Alto, CA) contains the Enhanced Green Fluorescent Protein (EGFP) gene under the control of the cytomegalovirus promoter. Plasmids were prepared from transformed DH5 $\alpha$ Escherichia coli using the Maxiprep DNA purification system according to manufacturer instructions (Qiagen, Chatsworth, CA). This pDNA was stained stoichiometrically with a $30.4 \times 10^{-5} \mathrm{~mol} / \mathrm{L}$ TOTO-1 solution (Molecular Probes ${ }^{\circledR}$, InvitroGen $^{\mathrm{TM}}$, Eugene, OR), for $1 \mu \mathrm{g} / \mu \mathrm{L}$ pDNA solution during $60 \mathrm{~min}$ on ice (e.g. an average base pair to dye ratio of 5) (Escoffre et al., 2009b; Rye et al., 1992).

After the $M \beta C D$ incubation, the cells were centrifuged ( $5 \mathrm{~min}$, $120 \mathrm{~g}$ ) and suspended in $100 \mu \mathrm{L}$ pulsation buffer containing $2 \mu \mathrm{g}$ labeled pDNA at a rate of $2 \times 10^{5}$ cells per condition. For this pur- pose, each suspension was deposited between the rod-electrodes which were previously fixed on the Lab-Tek ${ }^{\circledR}$-II installed on the fluorescence microscope. The electric field parameters were as described above with strengths between 0.4 and $1 \mathrm{kV} / \mathrm{cm}$.

Cells were observed with a Leica $100 \times, 1.3$ numerical aperture oil immersion objective mounted on a Leica DMIRB inverted microscope (Leica Microsystems GmbH, Wetzlar, Germany). The excitation source was a Leica mercury lamp $100 \mathrm{HBO}$. The wavelengths were selected using the Leica L4 filter block $\left(450 \mathrm{~nm} \leq \lambda_{\mathrm{ex}} \leq 490 \mathrm{~nm}\right.$; dichroic mirror pass band, $\left.515 \mathrm{~nm} \leq \lambda_{\mathrm{em}} \leq 560 \mathrm{~nm}\right)$. Images were recorded with the CellScan System from Scanalytics (Billeria, MA) equipped with a cooled charge-coupled device camera (Princeton Instruments, Trenton, $\mathrm{NJ}$ ). This digitizing set-up allowed for quantitative localized analysis of the fluorescence emission along the cell membrane. Plot histograms detected local fluorescence intensity increase above the background level outside of the cells. Two characteristic parameters were used: the peak intensity and the integral under the peak. Both were directly related to the number of fluorescent molecules locally present (Faurie et al., 2010).

Cells were also transferred in PBS buffer and analyzed using flow cytometry (FACScan, BD Biosciences, Le Pont de Claix, France) via the channel FL1 $\left(510 \mathrm{~nm} \leq \lambda_{\mathrm{em}} \leq 540 \mathrm{~nm}\right)$. The percentage of fluorescent cells gives the percentage of cells being in interaction with the labeled pDNA and the mean fluorescence intensity associated is proportional to the mean amount of pDNA in interaction with the cells.

\subsection{Gene electrotransfer}

Cell suspensions were cultured at a density of $10^{6}$ cells $/ \mathrm{mL}$ in spinners, treated or not with $\mathrm{M} \beta C D$, and centrifuged to remove the media. They were suspended in the pulsation buffer containing $2 \mu \mathrm{g}$ pEGFP-C1 plasmid DNA and $10^{6}$ cells per condition. The pulse parameters were 10 pulses of $5 \mathrm{~ms}$ at $1 \mathrm{~Hz}$ with amplitudes varying between 0.4 and $0.8 \mathrm{kV} / \mathrm{cm}$. After the $5 \mathrm{~min}$ waiting time to allow cells to return to the impermeable state, cells were seeded in $35 \mathrm{~mm}$ Petri dishes for $24 \mathrm{~h}$ in the culture medium (see Section 2.1). Subsequently, they were washed, harvested with trypsin-EDTA, suspended in PBS, and analyzed using flow cytometry (FACScan, BD Biosciences, Le Pont de Claix, France) via the channel FL1 $\left(510 \mathrm{~nm} \leq \lambda_{\mathrm{em}} \leq 540 \mathrm{~nm}\right)$. The percentage of fluorescent cells gives the percentage of EGFP transfected cells (i.e. the efficiency of transfection) and the mean fluorescence intensity associated is proportional to the mean amount of EGFP expressed by the cell population (i.e. the level of transfection).

\subsection{Cell viability}

Cell viability was determined by the ability of cells to grow and divide over a $24 \mathrm{~h}$ period (corresponding to more than one generation) (Kueng et al., 1989). Viability was measured by monitoring cell growth through a coloration method with crystal violet (Merck \& Co., Whitehouse Station, NJ). After treatment, the cells were cultured to a density of $10^{6}$ cells $/ \mathrm{mL}$ in the culture medium on $35 \mathrm{~mm}$ Petri dishes for $24 \mathrm{~h}$. After 3 washings with PBS, the cells were incubated with $0.1 \%$ crystal violet in PBS for $20 \mathrm{~min}$ under gentle agitation $(20 \mathrm{rpm})$ at room temperature. Then, the cells were washed 3 times with PBS and lysed with $10 \%$ acetic acid (Sigma-Aldrich, St. Louis, MO) for 10 min under gentle agitation at room temperature. $100 \mu \mathrm{L}$ of the lysate was diluted in $2 \mathrm{~mL}$ PBS and the optical density (OD) was measured at $595 \mathrm{~nm}$. The OD is proportional to the amount of cells and the measurements were normalized in relation to the untreated cells (control condition) (Golzio et al., 1998). 


\subsection{Intracellular trafficking}

\subsubsection{Endocytotic markers}

The pDNA was covalently stained with Cy3 dye using the Label IT ${ }^{\circledR}$ Nucleic Acid Labeling Kit (Mirus ${ }^{\circledR}$, Madison, WI) according to manufacturer instructions. The endocytotic markers were Alexa Fluor $^{\circledR}$ 647-transferrin (Molecular Probes ${ }^{\circledR}$, InvitroGen ${ }^{\mathrm{TM}}$, Carlsbad, CA) to test for the clathrin-mediated endocytosis path or Alexa Fluor ${ }^{\circledR}$ 647-cholera toxin subunit B (Molecular Probes ${ }^{\circledR}$, InvitroGen ${ }^{\mathrm{TM}}$, Carlsbad, CA) to test for the caveolin/rafts-mediated endocytosis path. $24 \mathrm{~h}$ prior to electropulsation, $2 \times 10^{5}$ cells were cultured on Lab-Tek ${ }^{\circledR}$ II slides. Then, the cells were incubated at $4{ }^{\circ} \mathrm{C}$ for $30 \mathrm{~min}$ to inhibit any endocytotic processes. The cells were subsequently washed with pulsation buffer and pulsed in $300 \mu \mathrm{L}$ pulsation buffer containing $1 \mu \mathrm{g}$ Cy3-labeled pDNA with the $10 \mathrm{~mm}$ length plate-electrodes. Five minutes after electropulsation, the pulsation buffer was removed and ice cold culture medium containing the endocytotic marker, either $50 \mu \mathrm{g} / \mathrm{mL}$ transferrin or $1 \mu \mathrm{g} / \mathrm{mL}$ cholera toxin subunit B, was added. The cells were again incubated at $4{ }^{\circ} \mathrm{C}$ for $30 \mathrm{~min}$ to allow for the endocytotic marker to interact with the plasma membrane without endocytosis taking place. Afterwards, the cells were incubated for $15 \mathrm{~min}$ at $37^{\circ} \mathrm{C}$ to induce the endocytosis.

\subsubsection{Fluorescence microscopy}

A solid state laser (Cobolt Jive $561 \mathrm{~nm}, 75 \mathrm{~mW}$, Cobolt AB, Stockholm, Sweden) and a diode laser (HL6535MG $658 \mathrm{~nm}, 90 \mathrm{~mW}$ Hitachi, Thorlabs, Newton, NJ) were used to excite the Cy3 or Alexa Fluor $^{\circledR} 647$ labeled molecules. The laser powers were adjusted with neutral density filters. To obtain homogeneous illumination, the lasers were coupled into a multi-mode fiber $(0.22 \pm 0.02 \mathrm{NA}$, Optronis $\mathrm{GmbH}$, Kehl, Germany) which was shaken to destroy coherence and suppress interference effects. The fluorescence was collected using a $100 \times / 1.4$ NA oil objective (HCX PL APO, Leica Microsystems $\mathrm{GmbH}$, Wetzlar, Germany), separated from excitation light with a dual band dichroic mirror (HC Dualband Beamsplitter z561/660, Semrock, Rochester, NY). The fluorescence emitted from the green labels was selected using a long-pass filter (Raman emitter RU 568, Semrock, Rochester, NY) and a band-pass filter (BrightLine HC 593/40, Semrock, Rochester, NY). The fluorescence emitted from the red labels was selected using a long-pass filter (Raman emitter RU 664, Semrock, Rochester, NY). Images were recorded using an EMCCD camera (Andor iXON, Andor Technology PLC, Belfast, Ireland). Acquisitions were sequentially taken to avoid cross talk.

\subsubsection{Colocalization analysis}

The image processing and analysis were performed using Image ( $\mathrm{NIH}$, Bethesda, MD, USA) and a procedure adapted from (Lachmanovich et al., 2003). In detail, point noise on raw images was removed by applying a $3 \times 3$ pixels median filter. To remove diffuse background, an additional filtering step was performed. For this purpose, first the short morphology plugin of ImageJ was used with the size set to a circle with 15 pixels diameter. The resulting image was subtracted from the point noise filtered image. This process allows for the suppression of the background without significantly changing the relative intensities of the particles. Further object segmentation and quantification were performed with the JACoP plugin of Image (Bolte and Cordelieres, 2006). The latter was used to manually define the threshold above which all pixels are considered to be part of an object. The object counting module of the plugin gives the total number of particles and that of colocalizing ones for each channel. Two options are available for defining colocalization. The first, called the overlap approach, defines the center of mass of each object belonging to the group A (e.g. green detection channel) and tests if it falls into the area covered by an object belonging to the group B (e.g. red detection channel). Colocalization then is a match between the centers of mass of group A objects with the area covered by group B objects. The degree of colocalization is given by the percentage of $A$ objects colocalizing with $B$ objects. This operation can be performed separately for each channel. The second option to define colocalizing objects is called nearest neighbor distance approach. As with the overlap method, the center of mass of each object is defined, but this time for both groups. The software measures the distance between the centers of mass of A group objects and the centers of mass of B group objects. As the number of objects often differs from one channel to the other, the program selects the channel with fewer objects and searches the nearest neighbor in the second channel which has more objects. If this distance is found to be below the optical resolution of the acquisition system, the two objects are considered to be colocalized. The degree of colocalization is then given by the percentage of objects in the first channel colocalizing with objects of the second channel.

\subsection{Statistical analysis}

Error bars represent the standard error of the mean (SEM). The statistical significances of differences between the control and the $\mathrm{M} \beta C \mathrm{CD}$ treated cells for all experiments were evaluated using a paired Student's $t$-test. The degree of significance is given with these following labels: NS, not significant; ${ }^{*} p<0.05 ;{ }^{* *} p<0.01$; ${ }^{* * *} p<0.001$.

\section{Results}

First, we analyzed the effect of cholesterol depletion on the different steps involved in the pDNA electrotransfer process: membrane electropermeabilization, pDNA/membrane interaction, and gene expression. Then, we determined the mechanism of pDNA translocation through the plasma membrane and its intracellular trafficking using endocytotic markers. For that, cells were pulsed under electric field parameters which were known from previous studies to lead to efficient gene expression.

\subsection{Effect of cholesterol depletion on electrotransfection steps}

In order to determine to what extent the cholesterol has an influence on gene electrotransfer, $\mathrm{CHO}$ cells were incubated with methyl- $\beta$-cyclodextrin $(\mathrm{M} \beta \mathrm{CD})$ ). Indeed, cyclodextrins are cyclic oligomers of glucose that have the ability to sequester lipophiles in their hydrophobic core (Pitha et al., 1988). Treatment of cell culture with the $M \beta C D$ drug results in depletion of cholesterol from the plasma membrane followed by dissociation of proteins from rafts (Simons and Toomre, 2000) and disturbance of clathrin-coated vesicles formation (Rodal et al., 1999). Therefore, $M \beta C D$ can affect clathrin- and caveolin/raft-mediated endocytosis. Our experimental conditions induced approximately $40 \%$ cholesterol depletion with a rather low reduction of the phospholipids/proteins ratio (12\%). This depletion rate remained stable for up to $2 \mathrm{~h}$. These conditions allowed preserving the cell viability at a high level (up to $80 \%)$.

\subsubsection{Effect of cholesterol depletion on membrane electropermeabilization}

The results regarding the uptake of propidium iodide into control and cholesterol depleted $\mathrm{CHO}$ cells exposed to electric pulse series are shown in Fig. 1. In the absence of an electric field, 25-30\% of the cells were fluorescent due to the presence of dead cells in the population. This percentage was the same for the control as well as the cholesterol depleted cells (Fig. 1a). The application of electric field pulses resulted in the permeabilization of cells. The percentage of electropermeabilized $\mathrm{CHO}$ cells was not affected by cholesterol 

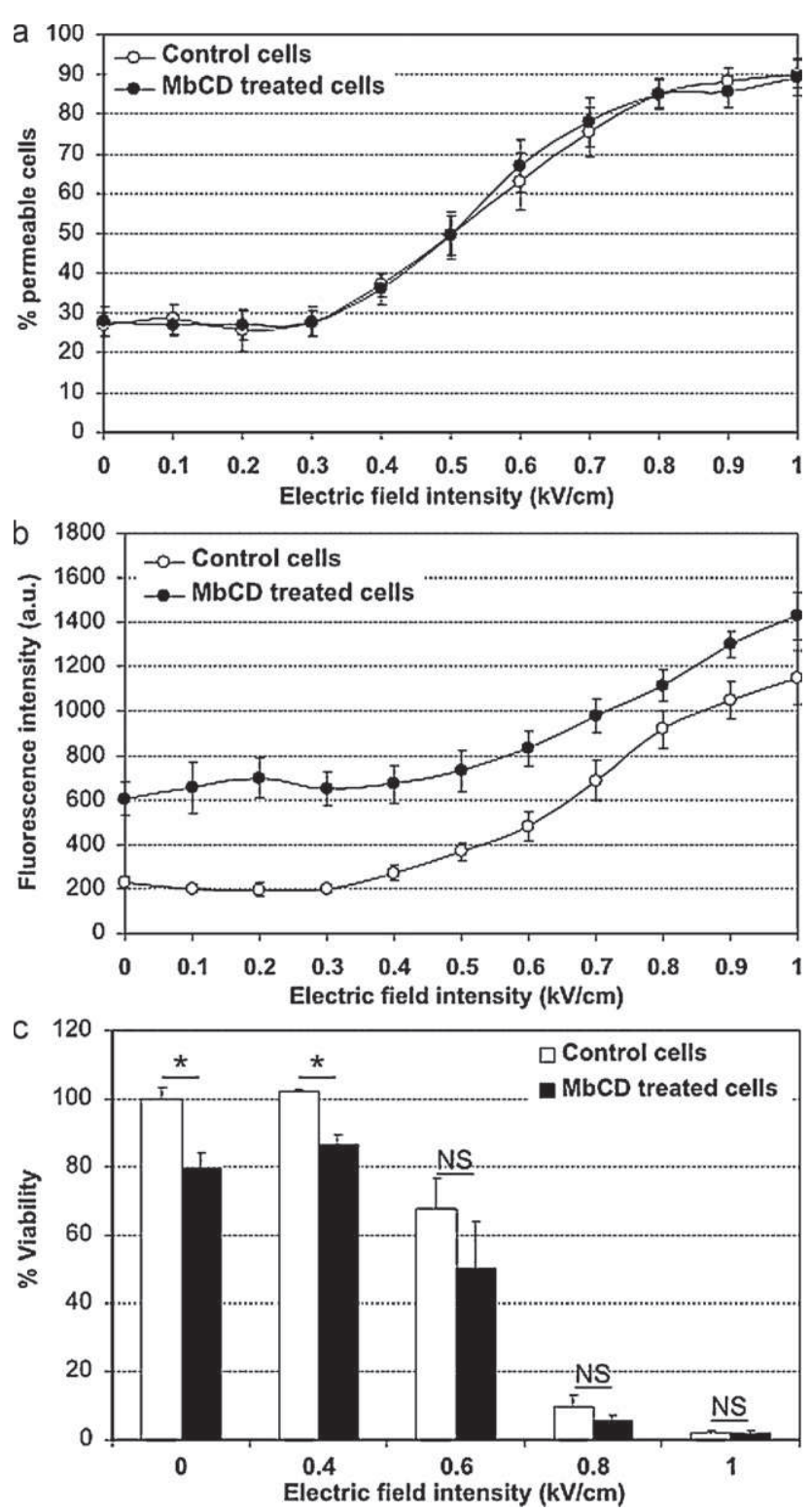

Fig. 1. Effect of cholesterol depletion on the electropermeabilization of $\mathrm{CHO}$ cells. Cells were incubated with the drug $\mathrm{M} \beta \mathrm{CD}$ for $15 \mathrm{~min}$ and exposed to an electric field. 10 pulses of $5 \mathrm{~ms}$ at $1 \mathrm{~Hz}$ with strengths varying between 0 and $1 \mathrm{kV} / \mathrm{cm}$ were applied. The membrane permeabilization was detected by propidium iodide uptake and measured using flow cytometry. (a) Percentage of permeabilized cells and (b) mean fluorescence intensity. The white dots represent the control cells, i.e. not treated with the drug $M \beta C D$, the black dots correspond to the treated cells. (c) Cell viability of the control cells (white bars) and the cholesterol depleted cells (black bars). 8 independent experiments were performed.

depletion. The electropermeabilization threshold was $0.3 \mathrm{kV} / \mathrm{cm}$ for both control and treated cells. Above that threshold, an increase of the electric field strengths further increased the fraction of electropermeabilized cells. For an electric field strength of $0.8 \mathrm{kV} / \mathrm{cm}$, nearly $90 \%$ of all cells are permeabilized. Higher electric fields do not lead to a further increase in the number of permeabilized cells. The efficiency of permeabilization, related to the amount of molecules electrotransferred into the cells, was quantified by measuring the mean fluorescence intensity value of the cell populations (Fig. 1b). In the absence of electric fields, the native permeability was higher for the cholesterol depleted cells than for the control ones. The $M \beta C D$ treatment did not affect the mean fluorescence intensity of the PI (data not shown). In the presence of electric fields, the cell electropermeabilization was still higher for the $\mathrm{M} \beta \mathrm{CD}$ treated cells, but the effect of the electric field (the increase in fluorescence, i.e. in the amount of electrotransferred PI molecules) was the same as for the control cells. The difference in permeability between treated and untreated cells remained nearly constant for all electric field strengths. In addition, we determined the effect of electric pulses on the cell viability, which was measured $24 \mathrm{~h}$ later (Fig. 1c). As mentioned above, cholesterol depletion resulted in $20 \%$ decrease in cell viability. The effect of electropermeabilization on cell viability was the same for control and cholesterol depleted cells. In conclusion, cholesterol depletion did not significantly affect the electropermeabilization process, i.e. the electrotransfer of small molecules into cells and the cell viability. It only changes the native permeability of the $\mathrm{CHO}$ cells.

\subsubsection{Effect of cholesterol depletion on $\mathrm{pDNA} /$ membrane interaction}

Videomicroscopy at the single cell level offers direct access to the early events of pDNA delivery across the electropermeabilized membrane. Images of pDNA/membrane interaction were acquired using fluorescence microscopy with TOTO- 1 labeled pDNA in the minutes after application of the pulses. As previously described (Golzio et al., 2002) and as shown in Fig. 2a and b, pDNA interacted in the form of aggregates with the electropermeabilized part of the plasma membrane facing the cathode. This process is still present in cholesterol depleted cells. pDNA does not enter the cell during electropulsation, but instead it is trapped at the permeabilized membrane. Only several minutes after electropulsation is pDNA detected inside the cytoplasm. Consequently, the interaction of pDNA at the membrane level can be quantified. As shown in Fig. 2c, the amount of pDNA interacting with the permeabilized membrane of cholesterol depleted cells was not significantly different from that of control cells. Flow cytometry analysis showed similar results (Fig. 2d and e). Whatever the electric field strength applied, the number of cells interacting with the pDNA and the mean level of fluorescence intensity were not affected by the cholesterol depletion. In conclusion, the electro-mediated formation of pDNA aggregates with the cell membrane is not a cholesterol-dependent process.

\subsubsection{Effect of cholesterol depletion on gene transfer and expression}

To highlight any other steps of gene electrotransfer that may be affected by cholesterol, we measured EGFP gene expression of viable cells, which is the final step of the mechanism of gene electrotransfer. Without electropulsation, control and cholesterol depleted cells did not express EGFP (Fig. 3a and b). Moreover, the presence of the $M \beta C D$ drug does not affect the mean fluorescence intensity of the EGFP (data not shown). At the three electric field strength values leading to membrane permeabilization, cells expressed the EGFP reporter gene. Both the percentage of transfected cells and the associated fluorescence intensity of cholesterol depleted cells were dramatically lower than those of control cells. At $0.4 \mathrm{kV} / \mathrm{cm}$, cholesterol depletion induced a 3.5-fold decrease of the transfection efficiency compared to the control condition. At $0.6 \mathrm{kV} / \mathrm{cm}$, the transfection efficiency of cholesterol-depleted cells was 5 -fold lower than that of control cells and the transfection level decreased by a factor of 2 . The effect of cholesterol depletion on the transfection efficiency was less visible at $0.8 \mathrm{kV} / \mathrm{cm}$, but the transfection level decreased by a factor of 14 . Cell viability was the same for control and treated cells pulsed in the presence of pDNA(Fig. 3c). These results show that cholesterol can play a major role in the pDNA translocation through the membrane and/or its intracellular trafficking. 

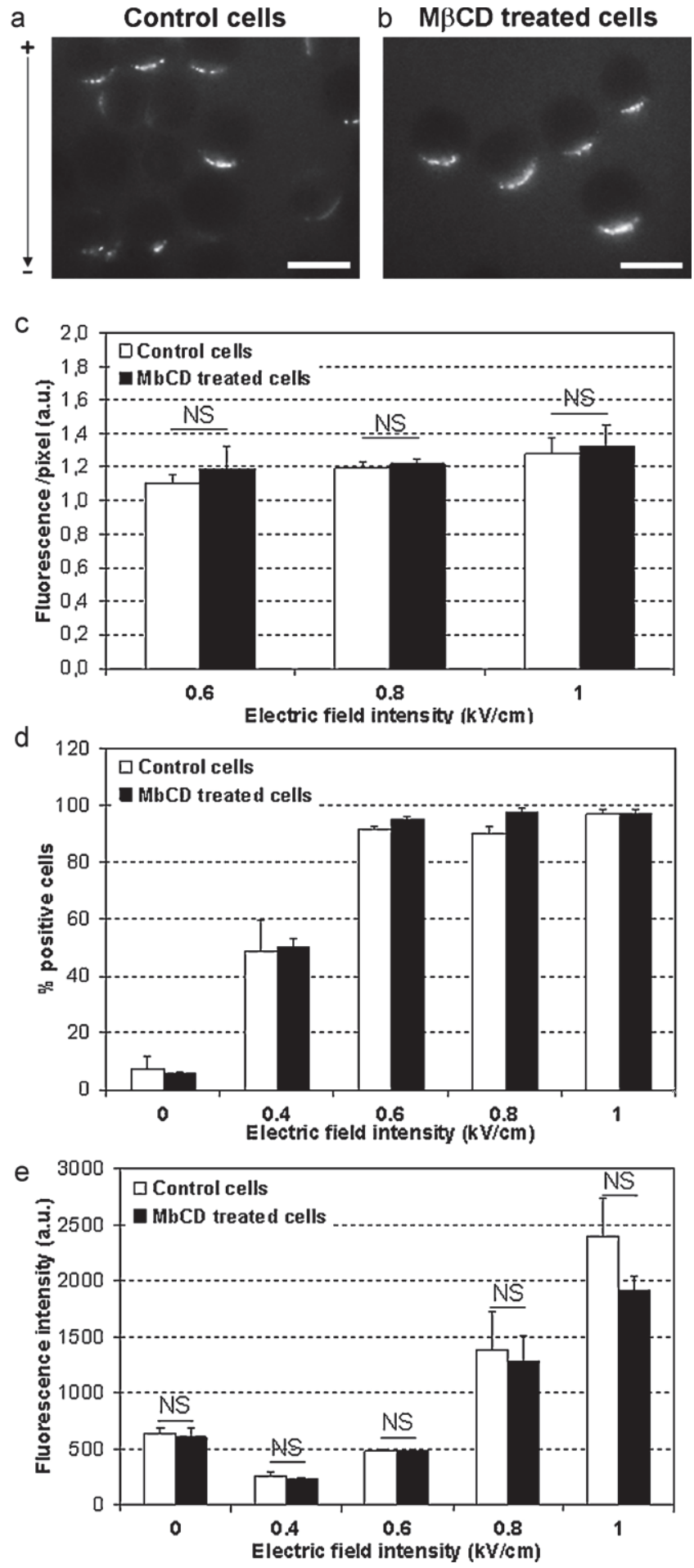

Fig. 2. Effect of cholesterol depletion on the pDNA/membrane interaction with $\mathrm{CHO}$ cells. Cells were incubated with the drug $M \beta C D$ for $15 \mathrm{~min}$ and exposed to an electric field. 10 pulses of $5 \mathrm{~ms}$ at $1 \mathrm{~Hz}$ with field strengths varying between 0 and $1 \mathrm{kV} / \mathrm{cm}$ were applied. The pDNA was labeled using TOTO-1 dye and observed using wide field microscopy. (a) Control cells and (b) treated cells (c) quantification of this interaction by measuring the fluorescence intensity and dividing it by the area of the interaction ( $n=30$ cells per condition). The TOTO- 1 -pDNA/membrane interaction was also quantified using flow cytometry giving access to $(\mathrm{d})$ the percentage of cells interacting with labeled pDNA and to (e) the associated mean fluorescence intensity. 3 independent experiments were performed. For all graphs, the white bars correspond to the control cells and the black ones to the cholesterol depleted cells. Scale bar $=15 \mu \mathrm{m}$.
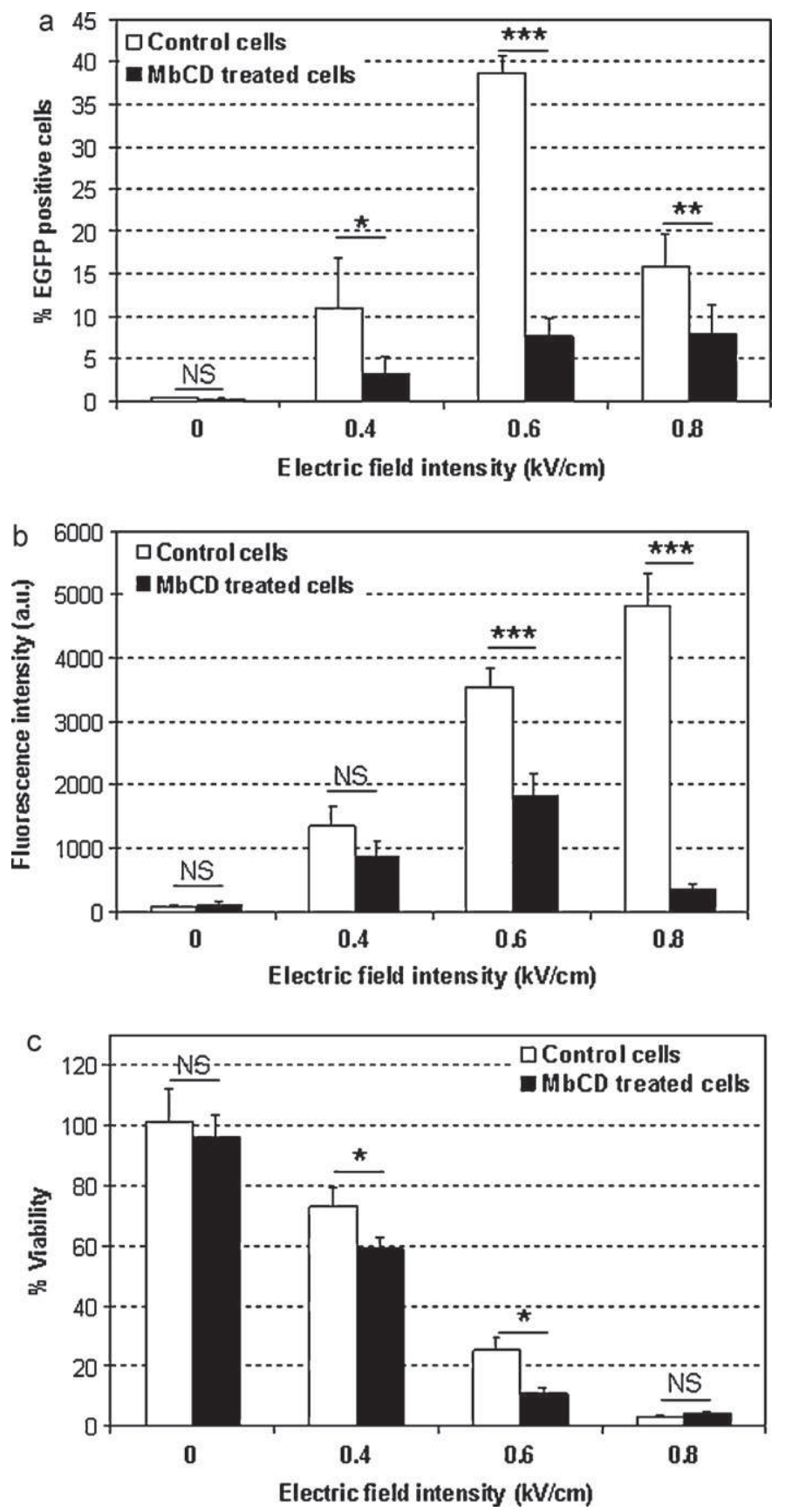

Fig. 3. Effect of cholesterol depletion on gene expression after electroporation of $\mathrm{CHO}$ cells. Cells were incubated with the drug $\mathrm{M} \beta \mathrm{CD}$ for $15 \mathrm{~min}$ and exposed to an electric field in the presence of pEGFP-C1. 10 pulses of $5 \mathrm{~ms}$ at $1 \mathrm{~Hz}$ with strengths varying between 0 and $1 \mathrm{kV} / \mathrm{cm}$ were applied. The EGFP protein expression was measured $24 \mathrm{~h}$ after the application of the electric field. (a) Percentage of cells expressing the EGFP protein, (b) mean fluorescence intensity of the EGFP protein, (c) cell viability. For all graphs, the white bars correspond to the control cells and the black ones to the cholesterol depleted cells. 4 independent experiments were performed.

\subsection{Colocalization study with endocytosis markers}

The effects of cholesterol depletion on gene electrotransfer, as well as the role of actin which we just reported (Rosazza et al., 2011), prompted us to determine the pathway of pDNA entry into the electropermeabilized cells. Indeed, both actin and cholesterol are involved in endocytotic processes. In order to determine the manner of pDNA entry after electropulsation, we performed dual color observations of Cy3-labeled pDNA and two endocytotic markers: Alexa Fluor ${ }^{\circledR} 647$ labeled transferrin (TF) to 

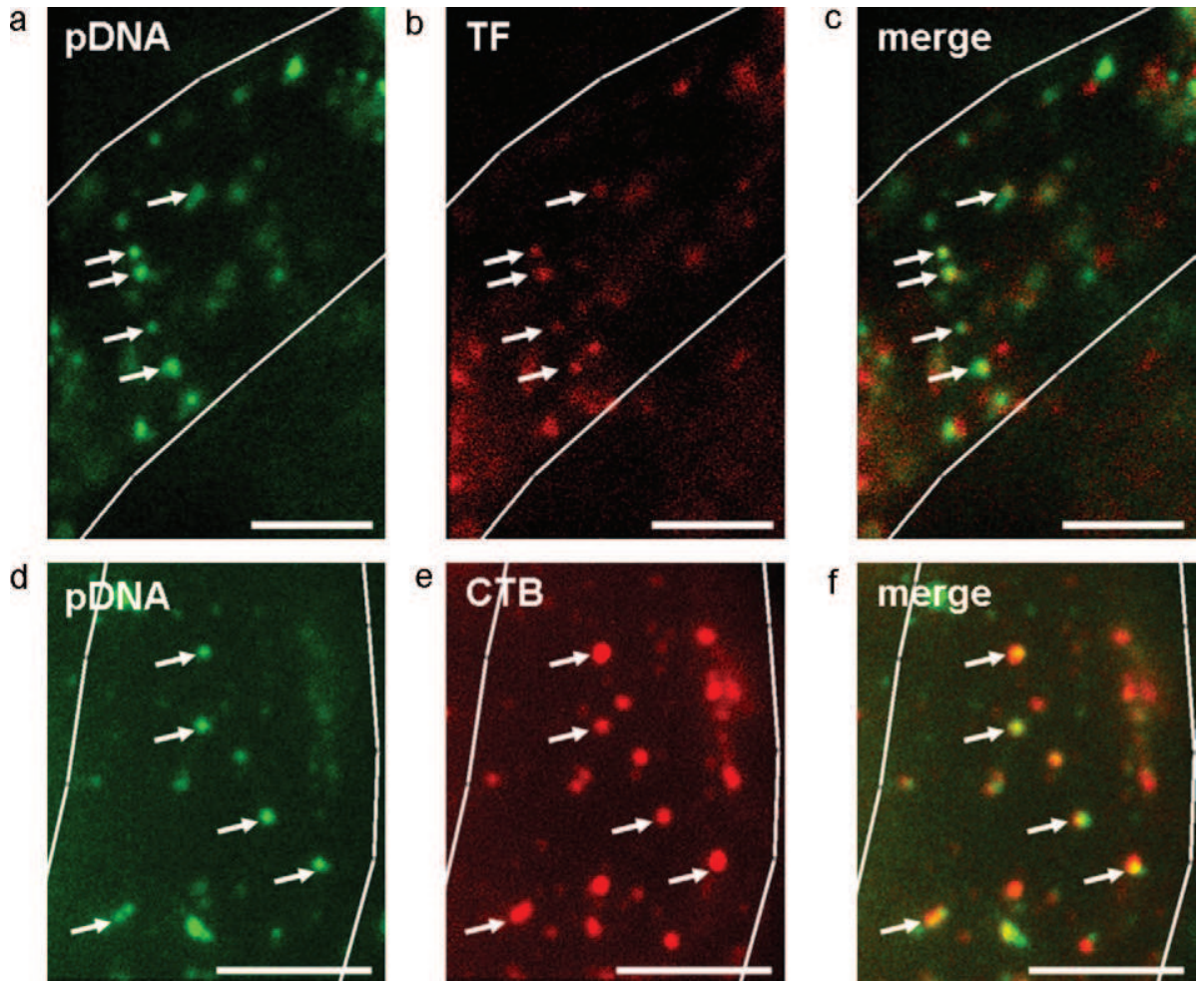

Fig. 4. Colocalization of pDNA with a clathrin-mediated endocytosis marker, transferrin and with a caveolin/raft-mediated endocytosis marker, cholera toxin subunit B. Cy3 labeled pDNA was electrotransferred onto CHO cells via the application of 10 electric pulses of $5 \mathrm{~ms}$ at $1 \mathrm{~Hz}$ and $0.4 \mathrm{kV} / \mathrm{cm}$. Observations either with Alexa Fluor ${ }^{\circledR} 647-$ transferrin, or with Alexa Fluor ${ }^{\circledR}$ 647-cholera toxin subunit B were performed using wide field microscopy. (a and d) pDNA, (b) transferrin, (e) cholera toxin subunit B, and ( $c$ and f) merge of the two channels. The white lines on the image represent the cell shapes. Scale bar $=5 \mu \mathrm{m}$.

assess the clathrin-mediated endocytosis and Alexa Fluor $^{\circledR} 647$ labeled cholera toxin subunit B (CTB) to evaluate the caveolin/raftmediated endocytosis.

In a first qualitative approach, microscopy data show that the pDNA partially colocalizes with both the TF and the CTB (Fig. 4). This means that pDNA is internalized, at least in part, via two endocytotic processes. To determine the involvement of each pathway in the pDNA internalization, colocalization quantification was performed using object-based approaches, which analyze the spatial distribution of the fluorescence signals (Lachmanovich et al., 2003). The colocalization analysis does not rely on the coincidence of individual pixels but on the coincidence of structures. Therefore, each pixel is not considered as a part of an image but as a part of a unique object. Object-based methods also discriminate better between signals coming from structures and those originating from background. These methods are of special interest for the analysis of subcellular structures having specific shapes and sizes close to the optical resolution limit of microscopes. After processing (Fig. 5a and c), the images are segmented (Fig. 5b and d red, patches). All the pixels above a limit value are considered to be part of an object. The edges of the fluorescent structures are then delimited. From each obtained object, the center of mass is determined (Fig. 5b and $\mathrm{d}$, green dots). The analysis using the overlap approach tests whether the centers of mass of objects in the first channel fall in areas covered by objects of the second channel (Fig. 5b and d). This can be done separately for both channels. The number of colocalizing objects (Fig. 5b and d, yellow dots) among the total amount of objects counted is calculated as the percentage of colocalization. The analysis using the nearest neighbor distance approach measures distances between the centers of mass of objects in the first channel and the centers of mass of objects in the second channel (Fig. 5f). These distances are compared to the optical resolution limit of the acquisition system. Two events colocalize when the distance of their centers of mass is below the optical resolution of the system (Fig. 5f, blue and purple dots). The degree of colocalization is also given as a percentage of objects of channel one colocalizing with channel two. Fig. 5g shows the two defined percentages of colocalization between the pDNA and the two endocytotic markers. The percentages of colocalization determined by the two different approaches yield a value of approximately $50 \% \pm 7 \%$ of colocalization of the pDNA with the CTB and of $25 \% \pm 7 \%$ with the TF. We therefore conclude that the main endocytotic process occurring during pDNA electrotransfer is caveolin/raft-mediated endocytosis. Clathrin-mediated endocytosis is also observed, but less frequently.

\section{Discussion}

The objectives of our work were to investigate the potential role of cholesterol in the process of pDNA electrotransfer and to characterize some routes of its internalization into cells. We first showed that the native cell permeability is affected by the plasma membrane cholesterol level. In agreement with previous investigations, this result can be explained by an increase in membrane fluidity, which is influenced by the cholesterol level. Indeed, the depletion or the addition of cholesterol in lipid vesicles or bilayer films, respectively, increases or decreases their permeability with respect to water, ions, glucose and other solutes (Lande et al., 1995; Mathai et al., 2008; Papahadjopoulos et al., 1972). Our data show that, whatever the electric field strength, cholesterol depletion has no significant effect on permeabilization level and efficiency accessed by PI uptake. These data are, to our knowledge, the first resulting from cell experiments. Previous data on the effect of cholesterol on membrane electropermeabilization have been obtained using molecular dynamics simulations and using lipid bilayers or vesicles as membrane models. They showed that membrane electroporation required an enhancement or a reduction of the electric field strength when the cholesterol content increased or decreased, respectively (Fernandez et al., 2010; Kakorin et al., 2005; 

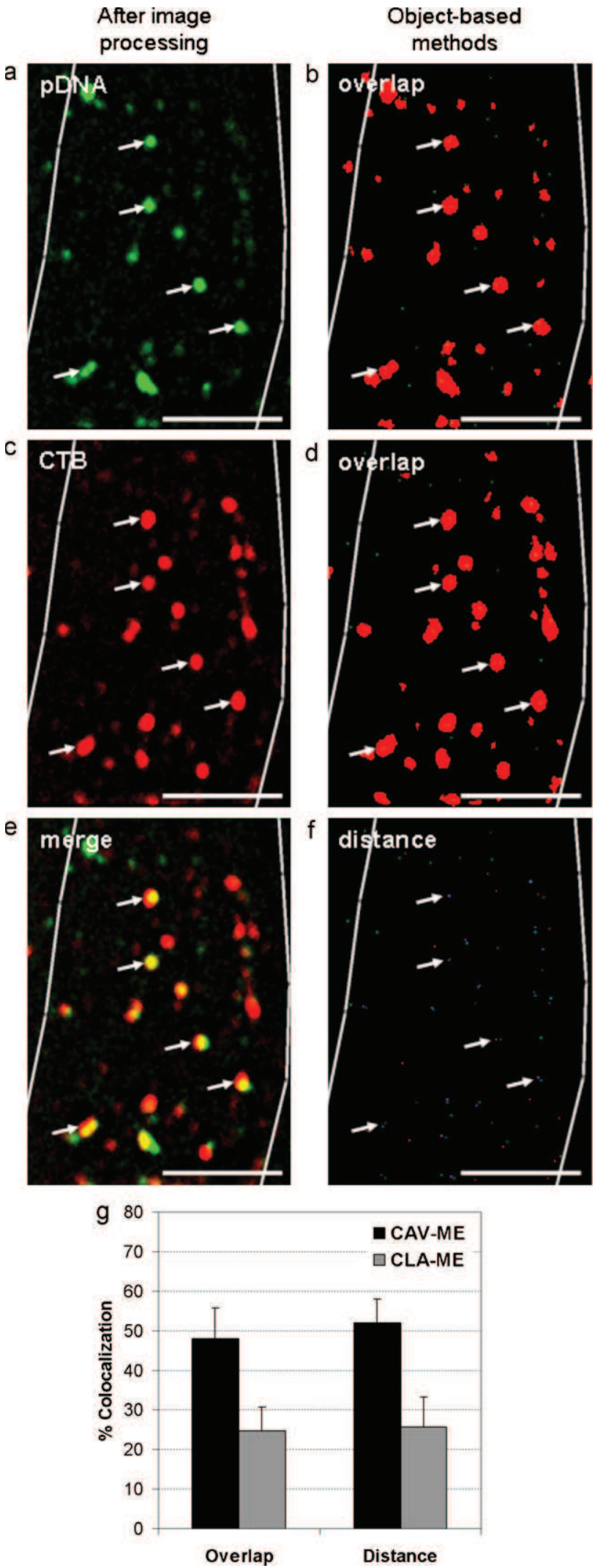

Fig. 5. Analysis of the colocalization of pDNA with a clathrin-mediated endocytosis marker, transferrin and with a caveolin/raft-mediated endocytosis marker, cholera toxin subunit B. The quantification was performed using object-based methods; the overlap approach and the nearest neighbor distance approach (Lachmanovich et al., 2003). The first step, common for the two methods of analysis, is the image processing giving such images: (a) pDNA channel, (c) cholera toxin subunit channel, and (e) merge of the two channels. For a comparison, the raw images are shown,
Koronkiewicz and Kalinowski, 2004; van Uitert et al., 2010). Moreover, simulation data showed that pore formation kinetics was under the control of cholesterol level. These differences between models and cells clearly show that the permeabilization of plasma membranes is more complex than that described by membrane models. This can be explained by the fact that the composition in proteins and in lipids of a plasma membrane (various phospholipids and proteins, membrane asymmetry, interaction with the cytoskeleton...) is much more complex compared to membrane models (one or three phospholipids) (van Meer et al., 2008).

We further show that cholesterol depletion has no effect on pDNA interaction with the plasma membrane subsequent to the electric field application, a key step of pDNA electrotransfer (Escoffre et al., 2010a; Faurie et al., 2010; Golzio et al., 2002; Phez et al., 2005). If membrane electropermeabilization is a necessary step for pDNA/membrane interaction to occur, the electrophoretically driven insertion of the pDNA in the plasma membrane is crucial for gene transfer. Cholesterol depletion seems to have no effect on either step. Increasing the electric field strength indeed enhances the pDNA insertion in the membrane in the same proportions for both the control and the cholesterol depleted cells. These results show that the pDNA/membrane interaction step is a cholesterol-independent process. Moreover, the cholesterol content cannot be an important parameter defining "competent sites" for pDNA/membrane interaction.

The results described above indicate that cholesterol might not have any involvement in the first steps of the gene electrotransfer process but, as gene expression is considerably affected in cholesterol depleted cells, further steps could be affected. Indeed, our results show that both transfection level and efficiency were dramatically lower compared to those of the control, for all electric field strengths applied. Cholesterol may have an involvement in the pDNA translocation across the plasma membrane and/or its intracellular trafficking. Because cholesterol is mainly found in plasma membranes, we propose that it is the translocation step that is altered by the reduction of cholesterol content. This has been demonstrated for the endocytosis of several different particles (Kabouridis et al., 2000; Lai et al., 2008; Norkin, 1999; Norkin et al., 2001; Rejman et al., 2004).

The colocalization studies performed in this work clearly show that pDNA is endocytosed. pDNA partially colocalized with both the cholera toxin subunit $\mathrm{B}$ and the transferrin. This means that caveolin/raft- as well as clathrin-mediated endocytosis is used by the electrotransferred pDNA to enter the cell. The quantification of the respective pathways indicates that around $50 \pm 7 \%$ of the pDNA enters into the cells via the caveolin/raft-mediated pathway and around $25 \pm 7 \%$ via the clathrin-mediated pathway. While previous works suggested that an endocytotic process could occur during gene electrotransfer (Antov et al., 2005; Klenchin et al., 1991; Rols et al., 1995; Satkauskas et al., 2001), this is the first time that this

respectively, in Fig. 4d-f. For the overlap approach, the ImageJ plugin JACoP tested whether the centers of mass of each green patch (shown as a green dot) falls within the area covered by a red patch. (b) pDNA as red patches and cholera toxin subunit $B$ as green dots, (d) cholera toxin subunit B as red patches and pDNA as green ones. Yellow color represents the colocalizing objects. For the nearest neighbor distance approach, the program tests the distance between the centers of mass of green objects and the centers of mass of red objects. (f) pDNA as green dots and cholera toxin subunit $B$ as red dots. When the distance is below the optic resolution limit of the acquisition system, the dots are, respectively, represented as blue and purple dots. In both cases, the percentages of colocalizing objects were thus calculated. The analysis of more than 100 cells with each endocytotic marker gave the percentages shown in the graph $(\mathrm{g})$. The black bars represent the percentages of colocalization with the cholera toxin subunit B, i.e. with the caveolin/raft-mediated endocytosis (CAV-ME on the graph), the grey bars represent the percentages of colocalization with the transferrin, i.e. with the clathrin-mediated endocytosis (CLA-ME on the graph). Scale bar $=5 \mu \mathrm{m}$. (For interpretation of the references to color in this figure legend, the reader is referred to the web version of this article.) 
is clearly demonstrated. These results may explain the decrease of gene expression observed when cells are cholesterol depleted. Since cholesterol is involved in endocytotic processes (Doherty and McMahon, 2009), its depletion is expected to reduce the endocytotic activity and may, in our case, reduce the pDNA uptake with a subsequent lower pDNA quantity reaching the nucleus and being available for gene expression to occur. This finally gives one explanation for the observation of reduced levels of gene expression in cholesterol depleted cells. One should note that cholesterol depletion may in addition reduce the further intracellular trafficking, endosomal escape, and/or nuclear targeting of the electrotransferred pDNA as it is the case for the adenovirus type 2 and the cholera toxin (Imelli et al., 2004; Shogomori and Futerman, 2001).

Around $75 \%$ of the pDNA during electrotransfer is internalized by concomitant clathrin- and caveolin/raft-mediated endocytosis. The pDNA aggregates interacting with the plasma membrane have sizes varying from 100 to $500 \mathrm{~nm}$ (Faurie et al., 2004, 2010; Golzio et al., 2002). This wide range of sizes may explain the several endocytotic pathways taken by pDNA. A study on the uptake of microspheres showed that particles up to $200 \mathrm{~nm}$ were internalized mainly by the clathrin-mediated pathway. With increasing diameters, a shift to a caveolin/raft-mediated endocytosis was observed and for $500 \mathrm{~nm}$ microspheres the latter was the predominant endocytotic pathway (Rejman et al., 2004). Thus, particle size in itself can determine which pathway is followed. The remaining $25 \%$ of pDNA for which we cannot clearly identify the internalization pathway could enter by one of the other endocytotic processes such as macropinocytosis. pDNA could, however, still enter cells via electropores. This hypothesis, even if not supported by experimental data at the present stage, still has to be considered as one potential way for pDNA to cross the plasma membrane as is postulated based on simulations (Smith et al., 2004) and on results based on pDNA electrotransfer in GUVs (Portet et al., 2011). In this last paper, it has been shown that the predominant pathway of electromediated pDNA uptake into liposomes is undoubtedly the electrophoretic entrance in a free form via defects created on the pole of the vesicles facing the cathode.

The fact that pDNA internalization is largely taking place via endocytosis allows speculations about the intracellular trafficking of the pDNA. Intracellular trafficking of endosomes is cell cytoskeleton based (Murray and Wolkoff, 2003). The actin cytoskeleton, in addition to being required for any endosome formation, can be used for the early step of the transport. Further long range transport takes place via the tubulin network. Previous studies have shown the involvement of both the actin and the tubulin networks in the mechanism of gene electrotransfer. Indeed, actin polymerization occurs at the membrane sites where the pDNA aggregates are formed and its alteration prior to gene electrotransfer reduces the pDNA accumulation at the membrane and the pDNA expression (Rosazza et al., 2011). Vaughan and Dean (2006) and Vaughan et al. (2008) have shown that a stabilization of the microtubule network enhances electrotransferred pDNA expression. They also demonstrated the ability of pDNA to interact with the microtubules via other proteins. Our findings are in agreement with these studies, as an endocytotic process requires the participation of the actin and the tubulin filaments. It, in addition, reinforces the hypothesis of an active intracellular transport of the pDNA.

In conclusion, we show that although cholesterol has no significant effect on the electropermeabilization and on the pDNA/membrane interaction steps, it is involved in later stages of gene electrotransfer. We report here, for the first time, that $50 \% \pm 7 \%$ of pDNA is internalized by caveolin/raft-mediated endocytosis and $25 \% \pm 7 \%$ by clathrin-mediated endocytosis. These data give important insight into the mechanism of gene electrotransfer even if the translocation step has still to be characterized. It has to be clarified how the remaining $25 \%$ of pDNA are internalized. Other endocytotic pathways may be involved as well as the transfer through electropores as reported in giant lipid vesicles (Portet et al., 2011).

\section{Acknowledgements}

We thank Elisabeth Bellard and Andrea Nagy for their help and the proofreading of this article. We acknowledge financial support from the Association Française contre les Myopathies (to M.-P.R.), from the Ministère des Affaires Etrangères et Européennes and the Deutscher Akademischer Austausch Dienst (program PHC PROCOPE).

\section{References}

Aihara, H., Miyazaki, J., 1998. Gene transfer into muscle by electroporation in vivo. Nat. Biotechnol. 16, 867-870.

Antov, Y., Barbul, A., Korenstein, R., 2004. Electroendocytosis: stimulation of adsorptive and fluid-phase uptake by pulsed low electric fields. Exp. Cell Res. 297 348-362.

Antov, Y., Barbul, A., Mantsur, H., Korenstein, R., 2005. Electroendocytosis: exposure of cells to pulsed low electric fields enhances adsorption and uptake of macromolecules. Biophys. J. 88, 2206-2223.

Bligh, E.G., Dyer, W.J., 1959. A rapid method of total lipid extraction and purification. Can. J. Biochem. Physiol. 37, 911-917.

Bolte, S., Cordelieres, F.P., 2006. A guided tour into subcellular colocalization analysis in light microscopy. J. Microsc. 224, 213-232.

Campana, L.G., Mocellin, S., Basso, M., Puccetti, O., De Salvo, G.L., Chiarion-Sileni, V., Vecchiato, A., Corti, L., Rossi, C.R., Nitti, D., 2009. Bleomycin-based electrochemotherapy: clinical outcome from a single institution's experience with 52 patients. Ann. Surg. Oncol. 16, 191-199.

Cemazar, M., Sersa, G., 2007. Electrotransfer of therapeutic molecules into tissues. Curr. Opin. Mol. Ther. 9, 554-562.

Cezanne, L., Navarro, L., Tocanne, J.F., 1992. Isolation of the plasma membrane and organelles from Chinese hamster ovary cells. Biochim. Biophys. Acta 1112 205-214.

Chernomordik, L.V., Sokolov, A.V., Budker, V.G., 1990. Electrostimulated uptake of DNA by liposomes. Biochim. Biophys. Acta 1024, 179-183.

Daud, A.I. DeConti, R.C. Andrews, S., Urbas, P. Riker, A.I., Sondak, V.K., Munster, P.N., Sullivan, D.M., Ugen, K.E., Messina, J.L., Heller, R., 2008. Phase I trial of interleukin-12 plasmid electroporation in patients with metastatic melanoma. J. Clin. Oncol. 26, 5896-5903.

Doherty, G.J., McMahon, H.T., 2009. Mechanisms of endocytosis. Annu. Rev. Biochem. 78, 857-902.

Escoffre, J.-M., Mauroy, C., Portet, T., Wasungu, L., Rosazza, C., Gilbart, Y., Mallet, L., Bellard, E., Golzio, M., Rols, M.-P., Teissié, J., 2009a. Gene electrotransfer: from biophysical mechanisms to in vivo applications. Biophys. Rev. 1, 177-184.

Escoffre, J.M., Bellard, E., Golzio, M., Teissie, J., Rols, M.P., 2009b. Transgene expression of transfected supercoiled plasmid DNA concatemers in mammalian cells. J. Gene Med. 11, 1071-1073.

Escoffre, J.M., Portet, T., Favard, C., Teissie, J., Dean, D.S., Rols, M.P., 2010a. Electromediated formation of DNA complexes with cell membranes and its consequences for gene delivery. Biochim. Biophys. Acta.

Escoffre, J.M., Teissie, J., Rols, M.P., 2010b. Gene transfer: how can the biological barriers be overcome? J. Membr. Biol. 236, 61-74.

Faurie, C., Phez, E., Golzio, M., Vossen, C., Lesbordes, J.C., Delteil, C., Teissie, J., Rols, M.P., 2004. Effect of electric field vectoriality on electrically mediated gene delivery in mammalian cells. Biochim. Biophys. Acta 1665, 92-100.

Faurie, C., Rebersek, M., Golzio, M., Kanduser, M., Escoffre, J.M., Pavlin, M., Teissie, J., Miklavcic, D., Rols, M.P., 2010. Electro-mediated gene transfer and expression are controlled by the life-time of DNA/membrane complex formation. J. Gene Med. 12, 117-125.

Fernandez, M.L., Marshall, G., Sagues, F., Reigada, R., 2010. Structural and kinetic molecular dynamics study of electroporation in cholesterol-containing bilayers. J. Phys. Chem. B 114, 6855-6865.

Fivaz, M., Abrami, L., van der Goot, F.G., 1999. Landing on lipid rafts. Trends Cell Biol. 9, 212-213.

Gabriel, B., Teissie, J., 1997. Direct observation in the millisecond time range of fluorescent molecule asymmetrical interaction with the electropermeabilized cell membrane. Biophys. J. 73, 2630-2637.

Gehl, J., 2008. Electroporation for drug and gene delivery in the clinic: doctors go electric. Methods Mol. Biol. 423, 351-359.

Giardino, R., Fini, M., Bonazzi, V., Cadossi, R., Nicolini, A., Carpi, A., 2006. Electrochemotherapy a novel approach to the treatment of metastatic nodules on the skin and subcutaneous tissues. Biomed. Pharmacother. 60, 458-462.

Glogauer, M., Lee, W., McCulloch, C.A., 1993. Induced endocytosis in human fibroblasts by electrical fields. Exp. Cell Res. 208, 232-240.

Golzio, M., Mora, M.P., Raynaud, C., Delteil, C., Teissie, J., Rols, M.P., 1998. Control by osmotic pressure of voltage-induced permeabilization and gene transfer in mammalian cells. Biophys. J. 74, 3015-3022. 
Golzio, M., Rols, M.P., Teissie, J., 2004. In vitro and in vivo electric field-mediated permeabilization, gene transfer, and expression. Methods 33, 126-135.

Golzio, M., Teissie, J., Rols, M.P., 2002. Direct visualization at the single-cell level of electrically mediated gene delivery. Proc. Natl. Acad. Sci. U.S.A. 99, 1292-1297.

Heller, L.C., Heller, R., 2010. Electroporation gene therapy preclinical and clinical trials for melanoma. Curr. Gene Ther. 10, 312-317.

Heller, R., Jaroszeski, M., Atkin, A., Moradpour, D., Gilbert, R., Wands, J., Nicolau, C., 1996. In vivo gene electroinjection and expression in rat liver. FEBS Lett. 389, 225-228.

Imelli, N., Meier, O., Boucke, K., Hemmi, S., Greber, U.F., 2004. Cholesterol is required for endocytosis and endosomal escape of adenovirus type 2. J. Virol. 78, 3089-3098.

Jerome, V., Heider, A., Schallon, A., Freitag, R., 2009. Exhaustive in vivo labelling of plasmid DNA with BrdU for intracellular detection in non-viral transfection of mammalian cells. Biotechnol. J. 4, 1479-1487.

Kabouridis, P.S., Janzen, J., Magee, A.L., Ley, S.C., 2000. Cholesterol depletion disrupts lipid rafts and modulates the activity of multiple signaling pathways in $\mathrm{T}$ lymphocytes. Eur. J. Immunol. 30, 954-963.

Kakorin, S., Brinkmann, U., Neumann, E., 2005. Cholesterol reduces membrane electroporation and electric deformation of small bilayer vesicles. Biophys. Chem. $117,155-171$.

Klenchin, V.A., Sukharev, S.I., Serov, S.M., Chernomordik, L.V., Chizmadzhev Yu, A., 1991. Electrically induced DNA uptake by cells is a fast process involving DNA electrophoresis. Biophys. J. 60, 804-811.

Koronkiewicz, S., Kalinowski, S., 2004. Influence of cholesterol on electroporation of bilayer lipid membranes: chronopotentiometric studies. Biochim. Biophys. Acta 1661, 196-203.

Kueng, W., Silber, E., Eppenberger, U., 1989. Quantification of cells cultured on 96well plates. Anal. Biochem. 182, 16-19.

Lachmanovich, E., Shvartsman, D.E., Malka, Y., Botvin, C., Henis, Y.I., Weiss, A.M., 2003. Co-localization analysis of complex formation among membrane proteins by computerized fluorescence microscopy: application to immunofluorescence co-patching studies. J. Microsc. 212, 122-131.

Lafont, F., Abrami, L., van der Goot, F.G., 2004. Bacterial subversion of lipid rafts. Curr. Opin. Microbiol. 7, 4-10.

Lai, C.H., Chang, Y.C., Du, S.Y., Wang, H.J., Kuo, C.H., Fang, S.H., Fu, H.W., Lin, H.H., Chiang, A.S., Wang, W.C., 2008. Cholesterol depletion reduces Helicobacter pylori CagA translocation and CagA-induced responses in AGS cells. Infect. Immun. 76, 3293-3303.

Lande, M.B., Donovan, J.M., Zeidel, M.L., 1995. The relationship between membrane fluidity and permeabilities to water, solutes, ammonia, and protons. J. Gen. Physiol. 106, 67-84.

Landstrom, F.J., Nilsson, C.O., Crafoord, S., Reizenstein, J.A., Adamsson, G.B., Lofgren, L.A., 2010. Electroporation therapy of skin cancer in the head and neck area. Dermatol. Surg. 36, 1245-1250.

Low, L., Mander, A., McCann, K., Dearnaley, D., Tjelle, T., Mathiesen, I., Stevenson, F., Ottensmeier, C.H., 2009. DNA vaccination with electroporation induces increased antibody responses in patients with prostate cancer. Hum. Gene Ther. $20,1269-1278$

Lowry, O.H., Rosebrough, N.J., Farr, A.L., Randall, R.J., 1951. Protein measurement with the Folin phenol reagent. J. Biol. Chem. 193, 265-275.

Mahrour, N., Pologea-Moraru, R., Moisescu, M.G., Orlowski, S., Leveque, P., Mir, L.M., 2005. In vitro increase of the fluid-phase endocytosis induced by pulsed radiofrequency electromagnetic fields: importance of the electric field component. Biochim. Biophys. Acta 1668, 126-137.

Manes, S., del Real, G., Martinez, A.C., 2003. Pathogens: raft hijackers. Nat. Rev. Immunol. 3, 557-568.

Mathai, J.C., Tristram-Nagle, S., Nagle, J.F., Zeidel, M.L., 2008. Structural determinants of water permeability through the lipid membrane. J. Gen. Physiol. 131, 69-76.

Maxfield, F.R., Tabas, I., 2005. Role of cholesterol and lipid organization in disease. Nature 438, 612-621.

Mazeres, S., Sel, D., Golzio, M., Pucihar, G., Tamzali, Y., Miklavcic, D., Teissie, J., 2009. Non invasive contact electrodes for in vivo localized cutaneous electropulsation and associated drug and nucleic acid delivery. J. Control. Release 134, 125-131.

Mir, L.M., Bureau, M.F., Gehl, J., Rangara, R., Rouy, D., Caillaud, J.M., Delaere, P., Branellec, D., Schwartz, B., Scherman, D., 1999. High-efficiency gene transfer into skeletal muscle mediated by electric pulses. Proc. Natl. Acad. Sci. U.S.A. 96, 4262-4267.

Mir, L.M., Glass, L.F., Sersa, G., Teissie, J., Domenge, C., Miklavcic, D., Jaroszeski, M.J., Orlowski, S, Reintgen, D.S, Rudolf, Z, Belehradek, M., Gilbert, R., Rols, M.P. Belehradek Jr. J., Bachaud, J.M., DeConti, R., Stabuc, B. Cemazar, M. Coninx, P. Heller, R., 1998. Effective treatment of cutaneous and subcutaneous malignant tumours by electrochemotherapy. Br. J. Cancer 77, 2336-2342.

Mir, L.M., Morsli, N., Garbay, J.R., Billard, V., Robert, C., Marty, M., 2003. Electrochemotherapy: a new treatment of solid tumors. J. Exp. Clin. Cancer Res. 22, 145-148.

Murray, J.W., Wolkoff, A.W., 2003. Roles of the cytoskeleton and motor proteins in endocytic sorting. Adv. Drug Deliv. Rev. 55, 1385-1403.

Neumann, E., Schaefer-Ridder, M., Wang, Y., Hofschneider, P.H., 1982. Gene transfer into mouse lyoma cells by electroporation in high electric fields. EMBO J. 1, 841-845.

Norkin, L.C., 1999. Simian virus 40 infection via MHC class I molecules and caveolae. Immunol. Rev. 168, 13-22.

Norkin, L.C., Wolfrom, S.A., Stuart, E.S., 2001. Association of caveolin with Chlamydia trachomatis inclusions at early and late stages of infection. Exp. Cell Res. 266, 229-238.
Papahadjopoulos, D., Nir, S., Oki, S., 1972. Permeability properties of phospholipid membranes: effect of cholesterol and temperature. Biochim. Biophys. Acta 266, 561-583.

Phez, E. Faurie, C. Golzio, M. Teissie, J. Rols, M.P., 2005. New insights in the visualization of membrane permeabilization and DNA/membrane interaction of cells submitted to electric pulses. Biochim. Biophys. Acta 1724, 248254.

Pitha, J., Irie, T., Sklar, P.B., Nye, J.S., 1988. Drug solubilizers to aid pharmacologists: amorphous cyclodextrin derivatives. Life Sci. 43, 493-502.

Portet, T., Camps i Febrer, F., Escoffre, J.M., Favard, C., Rols, M.P., Dean, D.S., 2009. Visualization of membrane loss during the shrinkage of giant vesicles under electropulsation. Biophys. J. 96, 4109-4121.

Portet, T., Favard, C., Teissie, J., Dean, D.S., Rols, M.-P., 2011. Insights into the mechanisms of electromediated gene delivery and application to the loading of giant vesicles with negatively charged macromolecules. Soft Matter 7, 38723881.

Pucihar, G., Kotnik, T., Miklavcic, D., Teissie, J., 2008. Kinetics of transmembrane transport of small molecules into electropermeabilized cells. Biophys. J. 95, 2837-2848.

Rejman, J., Oberle, V., Zuhorn, I.S., Hoekstra, D., 2004. Size-dependent internalization of particles via the pathways of clathrin- and caveolae-mediated endocytosis. Biochem. J. 377, 159-169.

Rodal, S.K., Skretting, G., Garred, O., Vilhardt, F., van Deurs, B., Sandvig, K., 1999. Extraction of cholesterol with methyl-beta-cyclodextrin perturbs formation of clathrin-coated endocytic vesicles. Mol. Biol. Cell 10, 961-974.

Rols, M.P., Delteil, C., Golzio, M., Dumond, P., Cros, S., Teissie, J., 1998. In vivo electrically mediated protein and gene transfer in murine melanoma. Nat. Biotechnol. $16,168-171$.

Rols, M.P., Femenia, P., Teissie, J., 1995. Long-lived macropinocytosis takes place in electropermeabilized mammalian cells. Biochem. Biophys. Res. Commun. 208, 26-35.

Rols, M.P., Tamzali, Y., Teissie, J., 2002. Electrochemotherapy of horses. A preliminary clinical report. Bioelectrochemistry 55, 101-105.

Rols, M.P., Teissie, J., 1998. Flow cytometry quantification of electropermeabilization. Methods Mol. Biol. 91, 141-147.

Rosazza, C., Escoffre, J.-M., Zumbusch, A., Rols, M.-P., 2011. The Actin Cytoskeleton Has an Active Role in the Electrotransfer of Plasmid DNA in Mammalian Cells. Mol Ther 19, 913-921.

Rosemberg, Y., Korenstein, R., 1997. Incorporation of macromolecules into cells and vesicles by low electric fields: induction of endocytotic-like processes. Bioelectrochem. Bioenerg. 42, 275-281.

Rouser, G., Fkeischer, S., Yamamoto, A., 1970. Two dimensional then layer chromatographic separation of polar lipids and determination of phospholipids by phosphorus analysis of spots. Lipids 5, 494-496.

Rye, H.S., Yue, S., Wemmer, D.E., Quesada, M.A., Haugland, R.P., Mathies, R.A., Glazer, A.N., 1992. Stable fluorescent complexes of double-stranded DNA with bisintercalating asymmetric cyanine dyes: properties and applications. Nucleic Acids Res. 20, 2803-2812.

Satkauskas, S., Bureau, M.F., Mahfoudi, A., Mir, L.M., 2001. Slow accumulation of plasmid in muscle cells: supporting evidence for a mechanism of DNA uptake by receptor-mediated endocytosis. Mol. Ther. 4, 317-323.

Sersa, G., Miklavcic, D., Cemazar, M., Rudolf, Z., Pucihar, G., Snoj, M., 2008. Electrochemotherapy in treatment of tumours. Eur. J. Surg. Oncol. 34, 232240.

Shogomori, H., Futerman, A.H., 2001. Cholesterol depletion by methyl-betacyclodextrin blocks cholera toxin transport from endosomes to the Golgi apparatus in hippocampal neurons. J. Neurochem. 78, 991-999.

Simons, K., Toomre, D., 2000. Lipid rafts and signal transduction. Nat. Rev. Mol. Cell Biol. 1, 31-39.

Smith, K.C., Neu, J.C., Krassowska, W., 2004. Model of creation and evolution of stable electropores for DNA delivery. Biophys. J. 86, 2813-2826.

Spugnini, E.P., Citro, G., D’Avino, A., Baldi, A., 2008. Potential role of electrochemotherapy for the treatment of soft tissue sarcoma: first insights from preclinical studies in animals. Int. J. Biochem. Cell Biol. 40, 159-163.

Teissie, J., Golzio, M., Rols, M.P., 2005. Mechanisms of cell membrane electropermeabilization: a minireview of our present (lack of ?) knowledge. Biochim. Biophys. Acta 1724, 270-280.

Titomirov, A.V., Sukharev, S., Kistanova, E., 1991. In vivo electroporation and stable transformation of skin cells of newborn mice by plasmid DNA. Biochim. Biophys. Acta $1088,131-134$

van Meer, G., Voelker, D.R., Feigenson, G.W., 2008. Membrane lipids: where they are and how they behave. Nat. Rev. Mol. Cell Biol. 9, 112-124.

van Uitert, I., Le Gac, S., van den Berg, A., 2010. The influence of different membrane components on the electrical stability of bilayer lipid membranes. Biochim. Biophys. Acta 1798, 21-31.

Vaughan, E.E., Dean, D.A., 2006. Intracellular trafficking of plasmids during transfection is mediated by microtubules. Mol. Ther. 13, 422-428.

Vaughan, E.E., Geiger, R.C., Miller, A.M., Loh-Marley, P.L., Suzuki, T., Miyata, N., Dean, D.A., 2008. Microtubule acetylation through HDAC6 inhibition results in increased transfection efficiency. Mol. Ther. 16, 1841-1847.

Yoshimori, T., Keller, P., Roth, M.G., Simons, K., 1996. Different biosynthetic transport routes to the plasma membrane in BHK and CHO cells. J. Cell Biol. 133, 247256.

Zlatkis, A., Zak, B., Boyle, A.J., 1953. A new method for the direct determination of serum cholesterol. J. Lab. Clin. Med. 41, 486-492. 